January 2003

\title{
Taxing Corporate Divisions
}

George K. Yin

\section{Recommended Citation}

George K. Yin, Taxing Corporate Divisions, 56 SMU L. REV. 289 (2003)

https://scholar.smu.edu/smulr/vol56/iss1/10

This Article is brought to you for free and open access by the Law Journals at SMU Scholar. It has been accepted for inclusion in SMU Law Review by an authorized administrator of SMU Scholar. For more information, please visit http://digitalrepository.smu.edu. 


\title{
Taxing Corporate Divisions
}

\author{
George K. Yin*
}

7 HE scope of a tax reform proposal is often determinative of its success. An otherwise rational proposal to reform the taxation of certain transactions, for example, may be less sensible once consideration is given to broader patterns and inconsistencies in the tax law. Nowhere is this more true than in the corporate tax area and subchapter $\mathrm{C}$ of the Code.

One of the major discontinuities in subchapter $\mathrm{C}$ is the disparate tax treatment of stock and asset acquisitions. Since the repeal of General Utilities, ${ }^{1}$ an acquisition of all of the assets of a target corporation may result in two immediate taxes if the target liquidates as part of the transaction. In contrast, an acquisition of all of the stock of the target generally results in only a single immediate tax even if the parties achieve the economic equivalent of the asset acquisition by subsequently liquidating the target into the acquiring corporation. ${ }^{2}$

This discontinuity challenges the coherence of much of subchapter C. Consider, for example, its impact in the corporate reorganization area. In order for a corporate asset acquisition to be tax-free at the corporate level, it must qualify as a "reorganization" and satisfy "continuity of interest." 3 In general, this means that some significant amount of the consideration provided by the acquiring corporation must consist of stock of that corporation. ${ }^{4}$ Yet a stock acquisition achieves "reorganization" consequences at the corporate level even if there is zero continuity of interest and the consideration consists entirely of cash. ${ }^{5}$

Into this confusion, Michael Schler boldly offers a series of proposals to reform the taxation of divisive reorganizations. ${ }^{6}$ He does not try first to level the landscape by reconciling (or assuming away) the stock/asset discontinuity of subchapter C. Rather, he places his ideas within the skewed

* Howard W. Smith Professor of Law, University of Virginia. Copyright @ 2002 George K. Yin. My thanks to Marty McMahon and Mark Yecies for their helpful comments on an earlier draft.

1. Gen. Utils. \& Operating Co. v. Helvering, 296 U.S. 200 (1935).

2. See George K. Yin, A Carryover Basis Asset Acquisition Regime?: A Few Words of Caution, 37 TAX Notes 415, 417 (1987); Eric M. Zolt, The General Utilities Doctrine: Examining the Scope of Repeal, 65 TAXES 819, 822-23 (1987).

3. See I.R.C. $\S \S 361(a), 368(a)$, (b) (2002); Treas. Reg. § 1.368-1(b) (2001).

4. See Treas. Reg. $\$ 1.368-1(\mathrm{e})(1)(\mathrm{i})$.

5. Cf. Am. Law Inst., Federal Income Tax Project: Subchapter C 72 (1982).

6. Michael L. Schler, Simplifying and Rationalizing the Spinoff Rules, 56 SMU L. Rev. 239 (2003). 
framework of current law. ${ }^{7}$

Mr. Schler's task is worthwhile (though daunting). Despite prodding by reformers over the last 16 years, Congress has not made any attempt to enact broad scale reform of subchapter $\mathrm{C}$, and there is no prospect of its doing so anytime soon. ${ }^{8}$ In the meantime, for reasons well described by Mr. Schler, $\S 355$ virtually cries out for reform. It is appropriate, therefore, to consider how to revise the divisive reorganization rules despite the uneven terrain on which those rules must be situated.

Mr. Schler's paper contributes many excellent suggestions to "eliminate unnecessary complexities and make the [divisive reorganization] rules more consistent with their purpose." 9 In this commentary, I review his proposals within the general context of current law-the ground rules laid out by him - and describe how a clarification of the purpose of $\S 355$ may lead to even greater simplification and coherence of the rule structure. Ultimately, however, true reform of $\S 355$ may have to await resolution of the more fundamental problems of subchapter C.

Part I of this paper discusses the purpose of $\S 355$ and part II sets forth the conditions necessary to implement that purpose. Part III contains my conclusion.

\section{THE PURPOSE OF SECTION 355}

Mr. Schler initially describes the purpose of $\S 355$ as "allow[ing] a single preexisting corporation or corporate group to be divided into parts among its shareholders." $10 \mathrm{He}$ subsequently elaborates and identifies three objectives for the provision: (1) make divisive transactions generally subject to the same requirements as those applicable to acquisitive reorganizations because of the close analogy between the two types of transactions; (2) prevent conversion of shareholder dividend income into

7. On two prior occasions, I have commented briefly on how $\$ 355$ might be made more rational. In one, I assumed that the tax consequence of a stock acquisition was the paradigm case. See George K. Yin, Taxing Corporate Liquidations (and Related Matters) After the Tax Reform Act of 1986, 42 TAx L. REv. 575, 661-64 (1987) [hereinafter Taxing Corporate Liquidations]. In the other, I basically assumed the opposite, with the tax consequence of an asset acquisition being the model result. See George K. Yin, Morris Trust, Sec. 355(e), and the Future Taxation of Corporate Acquisitions, 80 TAX Notes 375 (1998). In his paper, Mr. Schler clearly rejects the stock acquisition model, see Schler, supra note 6, at 266, but shows no sign of accepting the asset acquisition model either. Indeed, in prior writing, he has clearly rejected the asset acquisition paradigm. See Michael Schler, Yes to Section 355(e), No to Mandatory Section 338, Letter to the Editor, 80 TAx Notes 733, 735 (1998). Thus, he accepts the inconsistency of current law and attempts to devise a role for $\S 355$ within it. Current law, of course, is skewed in other respects. Certain businesses, for example, escape having to pay an entity-level tax altogether, and the U.S. tax treatment of an issue may be different from that of other countries. These considerations, which are beyond the scope of this paper, merely illustrate the enormity of the reformer's task.

8. Changes to subchapter $\mathrm{C}$ made by Congress and the Treasury Department during this period arguably point in different directions and none of them could even remotely be considered broad scale reform. $C f$. Michael L. Schultz, The Evolution of the Continuity of Interest Test, General Utilities Repeal and the Taxation of Corporate Acquisitions, 80 TAXES 229 (2002).

9. Schler, supra note 6 , at 240.

10. Id. 
capital gain; and (3) prevent improper avoidance of corporate-level tax when assets leave the corporate group. ${ }^{11}$ Unfortunately, this elaboration of the goals of the provision leads him astray, and makes certain of his proposals vulnerable to some of the same difficulties found in current law.

The first objective suggests a linkage between corporate and shareholder tax consequences. A qualifying acquisitive reorganization is taxfree at both the corporate and shareholder levels if, among other things, the transaction has a business purpose and satisfies continuity of interest and continuity of business enterprise. Thus, if a corporate division is taxfree because it is analogous to an acquisitive reorganization, the transaction should presumably be tax-free to both the shareholders and the distributing corporation under certain conditions.

In contrast, the second objective is exclusively focused on the shareholder consequences of the transaction, and is therefore not easily reconciled with the first objective. A good illustration of the problem involves the "device" clause, which is the quintessential provision intended to carry out the second objective. But why should qualification of a divisive transaction as a reorganization depend upon whether the transaction is "used principally as a device for the distribution of ... earnings and profits"? 12 Under current law, even as revised by Mr. Schler, that requirement leads to the nonsensical conclusion that the consequences to the distributing corporation are affected by, for example, the structure of the corporate division as a spinoff, splitoff, or splitup. ${ }^{13}$

It is also unclear whether the third objective can be reconciled with the first one, and current law reflects that uncertainty. On the one hand, $\S 355$ (d) and (e), provisions which most clearly try to achieve the third objective under current law, are expressly "delinked" from the rest of $\S 355$. Thus, they evidence a Congressional judgment that corporatelevel tax issues should not affect the tax consequences to the shareholders of the transaction or its qualification as a reorganization. On the other hand, exactly the opposite judgment is reflected by the 1987 amendment to $\S 355(b)(2)(D)$, which was added as an early and crude version of $\S 355(\mathrm{~d})$ and similarly intended to achieve the third objective. ${ }^{14}$ Failure to satisfy the amended requirement causes the entire transaction to lose its reorganization status, with resulting taxation at both corporate and shareholder levels. It seems inconceivable that both of these outcomes are correct.

11. Id. at $248-49$.

12. I.R.C. $\S 355(\mathrm{a})(1)$ (B) (2002).

13. See I.R.C. $\$ 355$ (c)(1); Treas. Reg. § 1.355-2(d)(2)(ii), -2(d)(5)(iv) (1992); $c f$. Jeffrey T. Sheffield \& Herwig J. Schlunk, Reconciling Spin-Offs with General Utilities Repeal, 74 TAXES 941, 943 (1996).

14. Cf. Boris I. Bittiker \& James S. Eustice, Federal Income Taxation of CorPORATIONS AND Shareholders 11-35 n.137 (7th ed. 2000); Richard L. Reinhold, Section 355(e): How We Got Here and Where We Are, 82 TAX NoTEs 1485, 1487 (1999). 
Finally, the third objective, on its own, is difficult to accomplish in the context of a typical divisive transaction. Assume that $P$ corporation owns all of the stock of $S$ corporation and in a spinoff, $P$ distributes all of the $S$ stock to the shareholders of $P$. In general, if there is a 50-percent-orgreater change of ownership of either $P$ or $S$ in connection with the spinoff, then either $\S 355(\mathrm{~d})$ or (e) causes the distribution to be taxable to the distributing corporation. As Mr. Schler notes, this result is consistent with the third objective if the change of ownership relates to $S$ but not if it relates to $P .{ }^{15}$ In the latter case, a disposition out of the corporate group of the $P$ assets triggers a tax measured by the amount of $P$ 's gain inherent in its stock in $S$. The problem is that the form of a corporate division does not match the tax objective identified for it.

In short, although Congress has articulated at various times all three of the objectives identified by Mr. Schler, it does not seem possible to draft a coherent statute that achieves all three. Like current law, Mr. Schler asks $\S 355$ to do too much and, as a result, the provision ends up not accomplishing any of its objectives very well. A slight clarification of the purpose of $\S 355$ is needed if we are to have a sensible set of rules in this area.

According to its legislative history, the original provision permitting tax-free treatment of a corporate division was enacted because the transaction was considered a form of corporate reorganization. ${ }^{16}$ As described in the regulations, the purpose of the acquisitive reorganization provisions is to "except from the general rule certain specifically described [transactions] incident to such readjustments of corporate structures . . . as are required by business exigencies and which effect only a readjustment of continuing interest in property under modified corporate forms." 17

A classic case illustrating the need for $\S 355$ is Rockefeller $v$. United States. ${ }^{18}$ In that case, the taxpayer's corporations were engaged in both the production and interstate transportation of oil. An adverse court decision permitted government regulation of the transportation end of the business. Consequently, to prevent government interference with the production activities, the taxpayer separated the two components of his corporations by transferring the transportation assets to newly formed subsidiaries and then spinning off the stock of the new subsidiaries pro

15. See Schler, supra note 6 , at 268 .

16. See H.R. Rep. No. 179, at 16 (1924), reprinted in J.S. Seidman, Seidman's Legis. Lative History of Federal InCOME TaX LaWs, 1938-1861, at 697 (1938) (divisive transaction is "common type of reorganization"); 65 CONG. REC. 2429 (1924) (statement of Rep. Green, Chairman, House Ways \& Means Comm.) (splitting of one corporation into two or more corporations is one of "usual forms of corporate reorganization").

17. Treas. Reg. $\$ 1.368-1(\mathrm{~b})$; $c f$. Treas. Reg. $\$ 1.355-2(\mathrm{~b})(1)$; STAFF of J. COMM. ON Tax'N, General Explanation of the Tax Reform ACt OF 1986, at 337 (1987) (stating that $\S 355$ provides tax-free treatment of a transaction that "merely effects a readjustment of the shareholder's continuing interest in the corporation in modified form"); Karla W. Simon \& Daniel L. Simmons, The Future of Section 355, 40 Tax Notes 291, 293 (1988).

18. Rockefeller v. United States, 257 U.S. 176 (1921). 
rata. There was clearly a non-tax business purpose for the separation. In addition, the taxpayer continued to own the stock in all of the resulting companies following the spinoff, with such stock merely representing the same underlying business interests indirectly owned by him prior to the transaction. Nevertheless, due to the absence of any statutory rule providing otherwise, the Supreme Court held that the receipt of the subsidiary stock was a taxable dividend to the taxpayer. Congress subsequently reversed this result by enacting the predecessor to $\S 355$ to provide nonrecognition treatment for such transactions. ${ }^{19}$ As in the case of an acquisitive reorganization, certain divisions of corporate structures driven by business exigencies, such as that involved in Rockefeller, should be taxfree to both the shareholders and the distributing corporation.

What type of divisive transaction should fall outside of $\S 355$ protection? Initially, almost any such transaction would seem to be a good candidate for "reorganization" and tax-free status because both shareholderlevel and corporate operating-level gains and losses can be fully preserved after the transaction. Moreover, the gain lost in the transaction if it is fully tax-free-the distributing corporation's gain in its stock in the controlled corporation-is a "third" level of tax that is frequently excused in subchapter $\mathrm{C}^{20}$ From this perspective, it might seem that reorganization status could be liberally granted to corporate divisions.

But in Rockefeller, Justice Pitney early recognized an important feature of a tax-free divisive transaction. After noting that the taxpayer did not dispose of any of the subsidiary stock following the distribution, the Court said:

Nevertheless the new stock [distributed to the taxpayer] represented assets of the [original] companies ... . that before had constituted portions of their surplus assets, and it was capable of division among stockholders as the [original] properties were not. The distribution, whatever its effect upon the aggregate interests of the mass of stockholders, constituted in the case of each individual a gain in the form of actual exchangeable assets transferred to him from the [original] company for his separate use in partial realization of his former indivisible and contingent interest in the corporate surplus. ${ }^{21}$

In other words, although the taxpayer immediately after the distribution merely owned the same underlying interests as he did prior to the transaction, the division provided him with an opportunity that he did not formerly have. After the division, the taxpayer was in a position to retain his pre-existing share of certain of the underlying interests while reducing his share of certain others, and to incur only a capital gains tax on the disposition. In contrast, absent the division, the taxpayer would generally have had to incur an ordinary income tax to achieve that same end. With-

19. Revenue Act of 1924, Pub. L. No. 176, § 203(h)(1)(B), 43 Stat. 253 (1924). (2000).

20. See, e.g., I.R.C. $\S \S 243(\mathrm{a}), 332(\mathrm{a}), 338(\mathrm{~h})(10)$ (2002); Treas. Reg. $\S 1.1502-13(\mathrm{f})$

21. Rockefeller, 257 U.S. at 183-84 (emphasis added). 
out a division, the taxpayer could have sold a portion of his stock in the entire enterprise with only a capital gains tax, but that sale would not have left him in the same economic position as his post-division situation.

Although not the focus of Justice Pitney's comment, a corporate division also provides the taxpayer with an opportunity to realize a corporatelevel tax advantage generally not present before the transaction. Consider a corporation with several businesses. Without a divisive transaction as a preliminary step, the taxpayer could not easily dispose of certain of the corporate businesses and retain certain others without having the corporation incur a corporate-level tax. An asset disposition by the corporation qualifying as a tax-free reorganization generally has to include "substantially all" of the properties of the corporation. ${ }^{22}$ A disposition of the stock of the corporation avoids a corporate-level tax, but that transaction reduces or eliminates the shareholder's interest in all of the corporation's underlying business interests. ${ }^{23}$ By permitting a corporate enterprise to be broken into smaller corporate structures, a tax-free divisive transaction thus enables the disposition of only certain businesses without corporate-level tax through either a stock or qualifying asset acquisition of the structure housing that business. The division creates the possibility of a disposition of selective corporate assets without corporate $\operatorname{tax}^{24}$

The recent case of South Tulsa Pathology Laboratory, Inc. v. Commissioner $^{25}$ provides an illustration of an attempt to achieve both of these advantages. In that case, the taxpayer was a corporation that decided to sell one of its two businesses to a buyer. Instead of a straight asset sale, which was the way the buyer preferred to carry out transactions like this, the taxpayer transferred the targeted business into a new subsidiary and then spun off the stock of the subsidiary pro rata among the taxpayer's shareholders. The shareholders then sold the buyer the stock of the former subsidiary holding the desired business. The court held that the spi-

22. See I.R.C. $\$ 368(a)(1)(C)$, (2)(D). The "straight" tax-free merger provision$\$ 368(\mathrm{a})(1)(\mathrm{A})$-does not contain a "substantially all" requirement, but without a pre-tailoring step, the merging corporation cannot pick and choose the assets to be acquired. See Rev. Rul. 2000-5, 2000-1 C.B. 436.

23. If the target corporation were organized with subsidiaries, it could dispose of certain subsidiaries and not others in a qualifying reorganization without incurring a corporate-level tax. See I.R.C. $\$ 368(\mathrm{a})(1)(\mathrm{B}),(2)(\mathrm{E})$. But distribution by the target of the acquiring corporation stock received in the reorganization would then trigger that tax (as well as a shareholder-level tax). See I.R.C. $\$ \$ 358(a)(1), 311(b)(1)$.

24. Granted, a taxpayer could have obtained this same benefit if it had had the foresight to incorporate the businesses in separate nonsubsidiary corporations from the outset. See Paul B. Stephan III, Disaggregation and Subchapter C: Rethinking Corporate Tax Reform, 76 VA. L. REv. 655, 684, 700 (1990). But that arrangement would have precluded the taxpayer from netting operating income and losses of the businesses with one another. $C f$. I.R.C. $\$ \S 1501,1504$ (a)(1)(A) (2002) (to be eligible to file a consolidated return, a group of corporations must have a common parent corporation). Thus, the taxpayer typically wants to have it both ways - to house the businesses within the same structure during their operating years and to house them within separate structures upon their disposition-with a tax-free division at the opportune time being the key to realizing both benefits.

25. S. Tulsa Pathology Lab., Inc. v. Comm'r, 118 T.C. 84 (2002). 
noff failed to qualify for tax-free treatment under $\S 355$ because of the device clause. ${ }^{26}$ The shareholders therefore were not permitted to convert what would otherwise have been ordinary income into capital gain. The court further observed that the transaction appeared to have been designed to avoid the corporate-level tax that would have arisen in a straight asset sale. ${ }^{27}$

The tax opportunities afforded by a corporate division thus provide natural parameters for its qualification as a tax-free transaction. A corporate division that simply facilitates a change in the ownership of any portion of the original corporate enterprise ought not to be a qualifying divisive reorganization. This conclusion is consistent with the description of a reorganization as "a readjustment of continuing interest in property under modified corporate forms." 28 Hence, to be tax-free, a corporate division must constitute only a reshuffling of a corporate structure among existing owners of that structure. ${ }^{29}$ The introduction to any significant extent of new ownership in any of the resulting parts of the corporate structure should disqualify the transaction from reorganization status.

In short, the function of $\S 355$ is to identify a certain class of divisive transactions that do not result in immediate taxation to either the shareholders or the distributing corporation. In general, qualifying transactions are reshufflings of corporate structures, driven by business exigencies, whose ownership remains, for the most part, at a standstill for some period surrounding the transaction.

Finally, this clarifying description of the purpose of the provision is in harmony with the tax consequences that arise in a nonqualifying transaction. As described by Treas. Reg. $\$ 1.368-1$ (b), the reorganization result is simply an exception from the "general rule." Therefore, a nonqualifying divisive transaction is ordinarily taxable to both the shareholders and the distributing corporation. In particular, the distributing corporation is taxed not because there has been a disposition of assets outside of the pre-existing corporate group, but because there has been a distribution of stock in a transaction that does not qualify for nonrecognition treatment. The "normal" result of this transaction is to measure the amount of gain based on the value and basis of the stock distributed. ${ }^{30}$ Thus, there is no longer any conceptual problem with the measurement of corporate-level gain resulting from the transaction.

26. Id. at 85 .

27. $I d$. at 96 .

28. Treas. Reg. $\S 1.368-1$ (b) (emphasis added).

29. Cf. Treas. Reg. $\$ 1.355-2$ (c)(1); Schler, supra note 6, at 262; Simon \& Simmons, supra note 17, at 293-94, 298.

30. See I.R.C. $\S \S 311(b)(1), 336(a)$ (2002). 


\section{IMPLEMENTING THE PURPOSE OF SECTION 355.}

\section{A. Prohibiting Ownership Change}

As described in part I, a key purpose of $\S 355$ is to make sure that qualifying corporate divisions do not result in any significant change in the ownership of any of the components of the corporate structure. Fortuitously, the triggering events in existing $\S 355(\mathrm{e})$ are available as a general model for implementing this purpose. That provision applies to any corporate division "which is part of a plan . . . pursuant to which one or more persons acquire directly or indirectly stock representing a 50-percent or greater interest in the distributing corporation or any controlled corporation." 31 A condition like this one can be used to qualify a transaction for $\S 355$ treatment. If a divisive transaction results in a change in interest of greater than $x$ percent in any of the corporate components of the transaction, then it is not a mere reorganization of continuing interests and is not entitled to tax-free treatment.

Some elaboration is necessary. First, $\S 355(\mathrm{e})$ turns on the existence of a "plan" and provides a rebuttable presumption that one exists if the change in ownership occurs during the four years immediately surrounding the distribution. ${ }^{32}$ Given the importance of this triggering event to the theory of $\S 355$, it might be preferable to provide both a flexible and fixed period within which the change of ownership may not occur. For example, an excessive change in interest within $y$ years surrounding the distribution or pursuant to a plan would cause loss of tax-free status. ${ }^{33}$ As a technical matter, this goal could be easily accomplished by creating an irrebuttable presumption of a plan for some appropriate period of time. ${ }^{34}$

Some might argue that a fixed period would be too restrictive. Under such a rule for example, an unanticipated change of ownership, such as a hostile acquisition of one of the corporate components following a corporate division, would cause the division to be fully taxable. But qualification for tax-free status need not turn on the good subjective intentions of the taxpayer. A division that ends up being part of an acquisition, whether planned or unplanned, is simply not a "mere" reshuffling of corporate interests among existing owners. On the contrary, such a transaction permits the taxpayer to take advantage of the tax opportunities created by the division. Accordingly, it need not qualify for tax-free status.

31. I.R.C. § 355(e)(2)(A)(ii) (2002).

32. I.R.C. $\$ 355(\mathrm{e})(2)$ (B) (2002).

33. Cf. BITTKER \& EustiCE, supra note 14, at 11-41 (suggesting possibility of fixed holding period as condition for $\$ 355$ ).

34. I do not express any opinion regarding whether the current interpretation of a "plan" in Treas. Reg. $§ 1.355-7 \mathrm{~T}$ is appropriate. For reasons described by Mr. Schler, the regulations may define that concept too loosely. See Schler, supra note 6, at 274 . Indeed, in certain respects, the regulations could be viewed as having unlawfully repealed the statutory requirement altogether. It is evident that the legislative and Treasury staffs did not see eye-to-eye on this provision. 
Second, the rules should make clear that changes of ownership in the corporate components among the existing owners of the enterprise do not disqualify the transaction. For example, the acquisition by a shareholder of stock of a controlled corporation by reason of the shareholder's ownership of the distributing corporation should not count as a change in the ownership of either corporation. ${ }^{35}$

Third, trading of portfolio interests in any of the corporations involved should not be treated as a change in ownership. The best way to implement this exception is to focus attention only on ownership changes involving shareholders owning over $z$ percent of the stock of a corporation. ${ }^{36}$ Moreover, for this purpose, passthrough entities should probably be looked through. Thus, a transfer of shares by a partnership, even though owning more than $z$ percent, would generally be disregarded; the focus instead would be on the amount of stock owned by, and changes in interest of, the partners of the partnership. ${ }^{37}$

Finally, certain transactions involving a corporate component of the divisive transaction, such as a complete liquidation, should be treated as a change of ownership of that component. In that case, the division would not simply be a "readjustment of continuing interest in property under modified corporate forms." 38 Thus, transactions like the one in Gregory v. Helvering ${ }^{39}$ would clearly fall outside of a qualifying, tax-free divisive reorganization.

\section{B. Simplification Facilitated by Ownership Change Condition}

With this single condition prohibiting certain changes of ownership in the distributing and controlled corporations, several other requirements of current $\S 355$ could be repealed or greatly simplified. Most obviously, continuity of interest would no longer be necessary. The rule against changes of ownership would essentially codify the continuity of interest requirement in this context. ${ }^{40}$

This codification might seem to be inconsistent with recent regulatory amendments liberalizing the meaning of continuity of interest in the acquisitive reorganization area. As a result of those amendments, dispositions of acquiring corporation stock not involving that corporation are

35. Cf. I.R.C. $\$ 355(\mathrm{e})(3)(\mathrm{A})(2002)$.

36. See Simon \& Simmons, supra note 17, at 297. Certain asset acquisitions, however, even if involving only public corporations, would constitute ownership changes. Cf. I.R.C. $\$ 355(\mathrm{e})(3)(\mathrm{B})$ (2002). More generally, the actions of shareholders acting in concert who collectively own over $z$ percent of the stock should not be disregarded even though no single shareholder owns as much as that amount.

37. Some other, more practical rule would need to be adopted to look through widely held passthrough entities, such as mutual funds. Cf. Schler, supra note 6, at 256.

38. Treas. Reg. $\$ 1.368-1$ (b) (emphasis added).

39. Gregory v. Helvering, 293 U.S. 465 (1935).

40. See Treas. Reg. $\$ 1.355-2$ (c)(1). This conclusion appears to be consistent with the role envisioned by Congress for $\$ 355$ (e). See H.R. ConF. REP. No. 105-220, at 529-30 (1997); Rev. Rul. 98-27, 1998-1 C.B. 1159; cf. Paul R. MCDaniel et al., Federal INcome Taxation of Business Organizations 1081-82 (3d ed. 1999). 
disregarded in determining whether continuity of interest is satisfied. ${ }^{41}$ In contrast, as just described, dispositions of distributing or controlled corporation stock during a period surrounding a corporate division would be extremely important in determining the tax-free status of the division.

The discrepancy illustrates the limits to the analogy between acquisitive and divisive reorganizations. Although the same term is used, "continuity of interest" has never meant the same thing in those two contexts, ${ }^{42}$ and the requirement serves different purposes. In an acquisitive reorganization, a former target shareholder who subsequently sells stock of the acquiring corporation obtains no tax advantage that did not exist prior to the reorganization. The same tax results-a potential capital gains tax to the shareholder and the absence of any corporate-level taxcould have been obtained through a sale of the target corporation stock prior to the reorganization. In contrast, as we have seen, a disposition of distributing or controlled corporation stock in connection with a divisive reorganization can result in tax advantages at both the shareholder and corporate levels. It is appropriate, therefore, to monitor closely dispositions in the latter case but not the former. ${ }^{43}$

It should also be possible to repeal most or all of the "device" clause. In general, that clause attempts to prevent bailouts through sales of distributing or controlled corporation stock subsequent to the division. ${ }^{44}$ But under the proposed change of ownership rule, if such sales occur within the prohibited period and exceed the permissible level, then taxfree status of the corporate separation would be lost and the device clause would not be needed.

There would be a continuing need to protect against dispositions falling within the permissible level. For example, suppose that only 50-percentor-greater changes in ownership of the distributing or controlled corporations within a particular period surrounding a corporate division would cause it to be taxable. In that case, a pro rata distribution of controlled corporation stock followed by sales of up to 50 percent of such stock might still be a qualifying division despite the potential tax advantage to the selling shareholders. It is possible that one or more of the other conditions for $\S 355$ (described below) would disqualify transactions like this. Alternatively, a straightforward way to address this problem would be to provide that planned dispositions of any interest in the distributing or controlled corporations would disqualify the transaction for tax-free

41. See Treas. Reg. § 1.368-1(e)(1)(i), -1(e)(6), ex. (1)(i).

42. Compare Treas. Reg. $\S 1.368-1(\mathrm{e})(1)(\mathrm{i})$, with Treas. Reg. $\S 1.355-2(\mathrm{c})(1)$.

43. If continuity of interest were interpreted in the same way for divisive reorganizations as it is for acquisitive reorganizations, then the focus would presumably be on the mixture of controlled corporation stock and boot distributed in the divisive transaction. Because the distributing corporation ordinarily must distribute all of its controlled corporation stock in order to qualify for $\S 355$ treatment, this narrow interpretation of continuity of interest would significantly reduce its importance as a qualifying condition for tax-free divisive reorganizations. Cf. David F. Shores, Reexamining Continuity of Shareholder Interest in Corporate Divisions, 18 VA. TAX Rev. 473, 542-43 (1999).

44. See Treas. Reg. $\$ 1.355-2(d)(1)$. 
treatment. ${ }^{45}$ Although it might seem harsh that a planned disposition of an insignificant amount of stock could cause the entire transaction to be taxable, that result is essentially what is authorized under current law. ${ }^{46}$ As a conceptual matter, the planned disposition would simply cause the transaction to fall outside of a mere reshuffling of corporate interests among existing owners. In any event, no matter how this problem is resolved, it would seem that much of the law pertaining to the device clause, including the bulk of the device and non-device factors, could be eliminated. ${ }^{47}$

Section 355(d) could also be repealed. There is substantial overlap in the triggering events of this subsection and those of $\S 355(\mathrm{e})$. Both apply in the event of a 50-percent-or-greater change of ownership in either the distributing or controlled corporation as part of the corporate division. ${ }^{48}$ The principal differences are: (1) \&355(d) prohibits the change of ownership during the five-year period immediately prior to the distribution whereas $\S 355(\mathrm{e})$ applies to ownership changes during a flexible period (part of a "plan") surrounding the time of distribution; and (2) § 355(e) extends to ownership changes not effected by "purchase," such as acquisitive reorganizations. ${ }^{49}$ The proposed ownership change rule should apply to an appropriate period of time surrounding the distribution and make $\S 355(d)$ unnecessary.

Finally, although the ownership change rule would generally be modeled after the triggering events of $\S 355(\mathrm{e})$, a remaining question is whether the provision's extension to ownership changes not effected by purchase should be retained. Or should revival of the Morris Trust transaction $^{50}$ be permitted? Section 355(e) originated as a limited effort to eliminate some nonsensical distinctions involving divisive transactions that had developed in the law. ${ }^{51}$ Subsequently, the role of the provision

45. Unplanned dispositions within $y$ years of the division would continue to be disqualifying only if they exceed a permissible level.

46. See Treas. Reg. $\$ 1.355-2$ (d)(2)(iii)(B) (planned disposition of stock following division is substantial evidence of device). Violation of the device clause might be avoided under current law if, for example, a provision like $\S 302$ (a) applied to the distributee in the absence of $\S 355$. See Treas. Reg. $\$ 1.355-2(\mathrm{~d})(5)$ (iv). But it is difficult to rationalize why the form of the distribution as a spinoff or splitoff should have an impact on the corporatelevel consequences of the distribution.

47. See Treas. Reg. § 1.355-2(d). Bear in mind that despite inclusion of the word "device" in the statute, the clause is not a general anti-avoidance rule. It is specifically directed towards a particular type of tax avoidance which is not relevant to determining whether a divisive transaction is analogous to a reorganization. Although Mr. Schler would retain the device clause, his support seems half-hearted and he points out in several places its inadequacies. See Schler, supra note 6, at 266, 272.

48. See I.R.C. \& 355(d)(2), (d)(3), (e)(2)(A)(ii).

49. Cf. 1.R.C. \& $355(\mathrm{~d})(5)$.

50. Comm'r v. Mary Archer W. Morris Trust, 367 F.2d 794 (4th Cir. 1966). "Morris Trust transaction" refers generically to a corporate division followed by a change in ownership of the distributing or controlled corporation by reason of an acquisitive reorganization of such corporation. The specific transaction involved in Morris Trust was not reversed by $\S 355(\mathrm{e})$.

51. See William D. Alexander et al., Taxation of Corporate Reorganizations, 13 ST. John's J. Legal Comment. 35, 50-51, 55 (1998) (comments of Glen Kohl, Deputy Ass't 
was expanded to treat certain leveraged transactions as, in effect, disguised changes of ownership carried out by purchase..$^{52}$ But the enacted provision goes far beyond these purposes. It causes the distributing corporation in a corporate division to recognize gain if there is a planned acquisitive reorganization of the distributing or controlled corporation.

Mr. Schler is one of the few defenders of the enacted version of the provision. Indeed, he has been described as one of only about six people (in the country?) who support the legislation. ${ }^{53}$ As he indicates in his paper, the majority of writers on this topic (including me) have taken the contrary view. ${ }^{54}$ The main argument to revive Morris Trust is that because an acquisitive reorganization, by definition, satisfies continuity of interest, a corporate division accompanied by such reorganization should not be viewed as in violation of that requirement. In other words, as I have asked on a prior occasion, if each step of the transaction-the division and the acquisitive reorganization-would be tax-free if unaccompanied by the other, what could possibly justify treating both steps, taken together, as a taxable transaction? ${ }^{55}$

But, on further reflection, my question may not be so telling after all. As described earlier, "continuity of interest" plays a different role, and has a different meaning, in the context of divisive and acquisitive reorganizations. Satisfaction of that requirement for one purpose, therefore, does not necessarily mean that there has been compliance with it for the other. Just as a qualifying acquisitive reorganization may not have a divisive element to it, ${ }^{56}$ so perhaps must a qualifying divisive reorganization not have an acquisitive element to it. Moreover, it does not matter whether the acquisitive element is carried out by reorganization or purchase. The reason is that either type of acquisition accompanying the corporate division enables the taxpayer to gain a tax advantage that would not otherwise have been available. For example, if the taxpayer in South Tulsa Pathology Laboratory, Inc. had arranged for an acquisitive reorganization of the corporation spun off to its shareholders, and the entire transaction was treated as tax-free, the taxpayer would have disposed of one business (and not the other) without an immediate corporate-level tax. This result is ordinarily unattainable in any other way.

Most critics of $\S 355(\mathrm{e})$ have emphasized that the Morris Trust transac-

Sec'y for Tax Policy, Dept. of Treasury, during the time $\S 355(\mathrm{e})$ was proposed and enacted); $c f$. Rev. Rul. 70-225, 1970-1 C.B. 80, made obsolete by Rev. Rul. 98-44, 1998-2 C.B. 315; Rev. Rul. 75-406, 1975-2 C.B. 125, made obsolete by Rev. Rul. 98-27, 1998-1 C.B. 1159.

52. See Reinhold, supra note 14 , at 1489-90.

53. See Alexander et al., supra note 51, at 50 (comment of Glen Kohl).

54. See Schler, supra note 6, at 272.

55. George K. Yin, Is Section 355(e) a Stalking-Horse for Mandatory Section 338?, Letter to the Editor, 80 TAX Notes 865 (1998).

56. See Helvering v. Elkhorn Coal Co., 95 F.2d 732 (4th Cir. 1937), cert. denied, 305 U.S. 605 (1938); Rev. Rul. 2000-5, 2000-1 C.B. 436; Calvin H. Johnson, A Full and Faithful Marriage: The Substantially-All-the-Properties Requirement in a Corporate Reorganization, 50 TAX Law. 319, 360 (1997). 
tion does not result in a tax-free step-up in basis. 57 What they overlook, however, is that a tax-free transaction without a step-up in basis is also generally a tax benefit in comparison to a result requiring the immediate recognition of gain. Moreover, as I have explained, this benefit is not easily obtained in other ways under current law for transfers of selective corporate assets or businesses. Indeed, even under the American Law Institute's elective carryover basis proposal, the tax benefit gained from a tax-free Morris Trust transaction would not necessarily be permitted. ${ }^{58}$

Thus, the answer to my earlier question is this: The combination of a tax-free division followed by a tax-free acquisition actually produces tax benefits greater than the sum of the benefits permitted by each transaction on its own. It is appropriate, therefore, to consider whether the two steps together should also be tax-free.

The proposed revision of $\S 355$ would go one step beyond current $\S 355(\mathrm{e})$ (and $\S 355(\mathrm{~d})$ ) by causing the shareholders as well as the distributing corporation to recognize gain if there is an impermissible change of ownership. The practical significance of this step is probably slight because the corporate-level tax alone will deter most taxpayers from engaging in a nonqualifying corporate division. Whatever its effect, the result follows logically from the theory behind the $\$ 355$ exception, and its absence from current law has been attributed to political, rather than policy, considerations. ${ }^{59}$

\section{Other Conditions}

This section sketches out the remaining conditions for a transaction to qualify as a tax-free divisive reorganization. Much of Mr. Schler's analysis of these issues seems exactly right and, therefore, the discussion is very brief.

Business purpose-As under current law, a qualifying transaction would need to have a business purpose. ${ }^{60} \mathrm{Mr}$. Schler would generally adopt the same test used in the acquisitive reorganization area with the following specific clarifications: (1) there would need to be a corporate business purpose as opposed to one merely affecting the shareholder's personal situation; (2) a purpose to enhance shareholder values would qualify as a corporate business purpose; (3) the business purpose requirement would rarely impede a corporate division carried out by a public

57. See, e.g., Hearing Before the Senate Fin. Comm. on Selected Revenue-Raising Provisions, 105th Cong., 35-36 (1997) (statement of Martin D. Ginsburg); N.Y. State Bar Ass'n, Comms. on Corporations and Reorganizations, Report on Section 355, at 8-9 (1997); Jeff Bell, General Utilities Repeal, Section 355(e), and the Triple Tax, 87 TAX Notes 1385, 1397 (2000); Reinhold, supra note 14, at 1493; Scott E. Stewart, Comment, New Rules for Spinoffs: An Analysis of Section 355(e), 51 TAx LAw. 649, 653 (1998).

58. See Am. Law InST., supra note 5, at 73, 97 (requiring a nonsubsidiary corporation to transfer at least "substantially all" or a "major portion" of its assets in order to be eligible for carryover basis election); Taxing Corporate Liquidations, supra note 7, at 659. 61 .

59. See Alexander et al., supra note 51, at 52-53 (comment of Glen Kohl).

60. See Treas. Reg. \& 1.355-2(b)(1). 
company; and (4) a purpose to facilitate dispositions of distributing corporation or controlled corporation stock would not be a qualifying business purpose. ${ }^{61}$ These are all sensible recommendations. I would add (if it need be said) that a qualifying purpose would not include the savings of federal taxes in order to reject the Eleventh Circuit's dicta on this issue in United Parcel Service v. Commissioner. ${ }^{62}$

Active business-It would also be appropriate to retain an active business requirement.63 This test would tend to ensure that a qualifying transaction involves a bona fide division of a corporate enterprise for valid business purposes. Here again, Mr. Schler makes several good suggestions including applying this test on a group-wide basis, taking into account active businesses conducted by foreign subsidiaries, and limiting the amount of nonbusiness assets held by the group. ${ }^{64}$ The 1987 amendment to $\S 355(\mathrm{~b})(2)(\mathrm{D})$ could also be repealed.

Control-Some type of control requirement also seems appropriate to ensure that the transaction constitutes a bona fide separation of a corporate enterprise. Mr. Schler's recommendation to adopt the definition of control in $\$ 1504(\mathrm{a})(2)$ seems correct. $^{65}$

Section 336(e)-Finally, Mr. Schler urges the promulgation of regulations under $\S 336(\mathrm{e})$ to permit the election contemplated by that provision. ${ }^{66}$ Under that election, the distributing corporation in a nonqualifying corporate division would not have to recognize gain upon distribution of controlled corporation stock so long as the controlled corporation is deemed to have sold and repurchased all of its assets in a taxable transaction. Thus, corporate gain or loss would be recognized by the controlled corporation and be accompanied by a change in its asset basis. This is a sound recommendation.

\section{CONCLUSION}

As described in this paper, it is possible to achieve significant simplification of $\S 355$, consistent with its role of not taxing business-driven divisions of corporate enterprises among existing shareholders. The key condition of a revised $\S 355$ would be to prohibit for a period of time an excessive change of ownership in either the distributing or controlled corporation. Additional conditions would include a valid business purpose for the transaction, an active business test, and a control requirement, all as modified by Mr. Schler. Existing provisions that could be repealed are

61. See Schler, supra note 6 , at $282-83$.

62. United Parcel Serv. v. Comm'r, 254 F.3d 1014, 1019 (11th Cir. 2001) (" "business purpose' does not mean a reason for a transaction that is free of tax considerations"); see Treas. Reg. \$ 1.355-2(b); George K. Yin, The Problem of Corporate Tax Shelters: Uncertain Dimensions, Unwise Approaches, 55 TAx L. REV. 405, 424-25 (2002).

63. I.R.C. $\S 355(\mathrm{a})(1)(\mathrm{C})$, (b).

64. See Schler, supra note 6 , at 283.

65. See id.

66. See id. at 281. 
continuity of interest, device, and $\S 355(\mathrm{~d})$, and $\S 355(\mathrm{e})$ would be replaced by the change of ownership condition.

There remains the difficult question of how well these revisions fit into the rest of the law. Much of the disagreement regarding the future of $\S 355$ has really been a debate about the proper taxation of corporate acquisitions. Under the stock acquisition paradigm, continuity of interest would generally be repealed for both acquisitive and divisive reorganizations and the shareholder- and corporate-level consequences of such transactions would be determined independent of one another. ${ }^{67}$ Under the asset acquisition paradigm, continuity of interest would assume heightened importance, with a sufficient change of ownership of a corporation triggering immediate taxation at both the shareholder and corporate levels. ${ }^{68}$

As noted at the outset, Mr. Schler for the most part eschews that larger debate, and this commentary has reviewed his proposals from the same vantage point, the ground rules laid out by him. But current law's inconsistencies provide treacherous footing for any reform effort. Depending upon one's perspective, it would be fairly easy to contend that the revisions described in this paper would tax divisive transactions either too early and often, or not early and often enough. Thus, although these proposals should provide a measure of improvement to the law, true reform of $\S 355$ must await the resolution of more fundamental issues.

67. See Am. Law Inst., supra note 5, at 32-43; Staff of Senate Comm. on Fin., 98TH Cong., The Reform and Simplification OF THE InCOME TAXation of Corporations, S. PrT. No. 98-95, at 59, 62 (Comm. Print 1983); Staff of Senate Comm. ON Fin., 99th Cong., The Subchapter C Revision Act of 1985, S. Prt. No. 99-47, at 50, 52 (Comm. Print 1985).

68. See James B. Lewis, A Proposal for a Corporate-Level Tax on Major Stock Sales, 37 Tax Notes 1041 (1987); David J. Shakow, Wither, “C”!, 45 TAx L. Rev. 177 (1990); Yin, supra note 2. 
[Vol. 56 